\title{
Diversity of Gold Deposits, Geodynamics and Conditions of Formation: A Perspective View
}

\author{
Franck Wilfried Dongmo Nguimatsia ${ }^{1,2^{*}}$, Anthony Temidayo Bolarinwa ${ }^{1}$, \\ Rose Fouateu Yongue ${ }^{2}$, Jean de Dieu Ndikumana ${ }^{1}$, \\ Jerry Olugbenga Olajide-Kayode ${ }^{1}$, Olugbenga G. Olisa1, \\ Maryam 0. Abdu-Salam', Marc Anselme Kamga'2, Ernest Serge Djou² \\ ${ }^{1}$ Department of Geology, Pan African University, Life and Earth Science Institute-University of Ibadan, Ibadan, Nigeria \\ ${ }^{2}$ Department of Earth Sciences, University of Yaounde 1, Yaounde, Cameroon \\ Email: *fnguim atsia-dongmo0116@stu.ui.edu.ng, *franckwilfried87@g mail.com
}

How to cite this paper: Nguimatsia, D.F.W., Bolarinwa, A.T., Yongue, R.F., de Dieu Ndikumana, J., Olajide-Kayode, J.O., Olisa, O.G., Abdu-Salam, M.O., Kamga, M.A. and Djou, E.S. (2017) Diversity of Gold Deposits, Geodynamics and Conditions of Formation: A Perspective View. Open Journal of Geology, 7, 1690-1709. https://doi.org/10.4236/ojg.2017.711113

Received: July 6, 2017

Accepted: October 16, 2017

Published: November 27, 2017

Copyright $\odot 2017$ by authors and Scientific Research Publishing Inc. This work is licensed under the Creative Commons Attribution International License (CC BY 4.0).

http://creativecommons.org/licenses/by/4.0/

\begin{abstract}
Gold occurs in a wide range of deposit types and settings. In the last decade, significant progress has been made in the definition, classification, characterization, thereby aiding understanding of the main gold deposit types. The present work aims to provide an update on the current state of knowledge on the different types of gold deposits models, geodynamics, their mode of formation and the condition suitable for their formation Several subsets of gold deposits are distinguished from one another on the bases of and their main geological models and their mode of formation described. Gold deposits of magmatic-hydrothermal origin are classified into Porphyry, Epithermal, Skarn, Iron Oxide-Copper-Gold and Intrusion related deposits; those of hydrothermal origin are Orogenic, Volcanogenic Massive Sulphide deposits, and Carlin-type; while those of Sedimentary Origin are placers. In terms of the major Period of gold deposit formation, the Mesoarchean was the largest gold period. Other gold peaks followed, particularly in the Neoarchean, Paleoproterozoic and Paleozoic while numerous and diverse gold deposit types were formed during the Cenozoic era.Wide varieties of geodynamic contexts in which each of the gold deposits are formed being explained while the conditions favourable for its formation are also being summarized. With the recent rise in the price of gold, mining companies and research centers continue to provide lighting of the key geology features of then ore-forming environments and the key geologic manifestations of the different deposit types.
\end{abstract}

\section{Keywords}

Gold, Tectonic, Porphyry, Epithermal, Skarns, Placer 


\section{Introduction}

Gold, a symbol of wealth, has been known and used by Man for at least 5000 years. Its usage spans various important fields, justifying the enthusiasm displayed by Man for this metal. It is a transition metal with atomic number 79, it is very dense (density 19.3 unit required) and malleable. In its natural state, gold occurs as the single stable isotope ${ }^{197} \mathrm{Au}$. Its most common oxidation state is zero $(0)$. Though, it can vary from $(-\mathrm{I})$ at $(+\mathrm{V})$, with $(+\mathrm{I})$ (called aurous ion) and (+III) (Auric ion) predominating. Gold is a relatively chemically stable metal, it does not form oxides or ions in aqueous solution, but it can form complexes with $\mathrm{CN}, \mathrm{Cl}, \mathrm{OH}$ or $\mathrm{HS}$. In its natural state, it occurs as native and form alloys with other elements like silver or tellurium, or as traces in the crystalline lattice of some minerals.

In spite of gold's relevance, prospecting for the metal is a laborious and complex venture due to its erratic distribution. Depletion of most of the world's shallow gold deposit cause a decrease in the world's gold supply and an increase in the international price of gold; in 2011, it reached a peak of 1800 USD per ounce. The consequence of this was a revival not only in the gold exploration and mining companies, but also on gold exploration research.

In a bid to curtail this problem and discover newer resources, researches have been undertaken in conjunction with mining companies to adequately study, characterise and classify gold deposits in order to ease exploration for newer deposits, and to improve exploitation of pre-existing ones. There has been many published research on gold deposit in the last decade, some of these research have led to significant improvement in the understanding of some gold deposits models; the definition of new types or sub-types of these deposits; and the introduction of new terms. However, significant uncertainty still remains regarding the specific distinction between some types of deposits and specific giant deposits are ascribed to different deposit types by different authors.

Gold is a siderophile element, it is part of the highly siderophile elements (HSE). Goldshmidt geochemical classification of elements defines Siderophile elements as those that have affinity for iron and migrated to the earth's core during the differentiation of the various crustal layers (Figure 1). A comparison of gold concentration between the silicate crust and chondrites suggests that $98 \%$ of terrestrial gold is contained in the core [1] [2] [3]. This siderophile character combined with the low abundance of gold in the chondritic earth and explains why it is found in small amounts in the earth's crust, making it a rare metal. The average concentration of gold is only $4 \mathrm{ppb}$ in the crust with the continental crust having $1.3 \mathrm{ppb}$ [4]. Due to its chemical stability, gold could sometimes concentrate locally in ore bodies and indicate a spike that can reach $10^{4}$ times the background concentration in the rest of the crust [3]. The factors that control its concentration at certain sites to deposit level in the Earth's crust and the ultimate source of the gold in the various deposits have remained topics of debate [3] [5] [6]. 


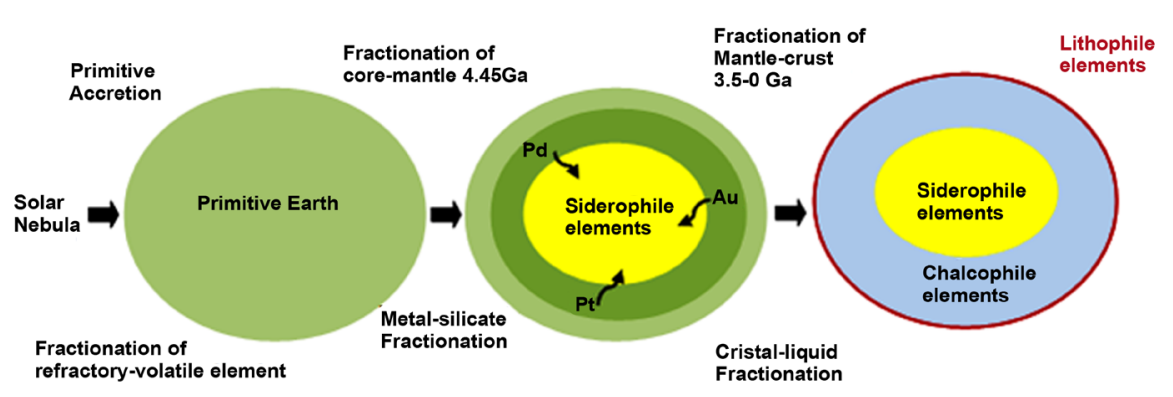

Figure 1. The different phases of differentiation of crustal layers, after [12].

Many classification schemes have been developed for subsets of gold deposits. These many classification schemes has provided additional points of view and expanded the nomenclature surrounding the problem of gold deposit classification. Examples of such gold deposits subset developed are, intrusion-related gold deposits [7], bulk mineable gold deposit [8], the epithermal gold deposits [9], or the epigenetic Archean gold deposits [10] [11] stated that a rational geological classification of the commonly recognized lode gold deposits is not feasible if it is not based on the geological settings of the deposits, host rocks, nature of mineralization and geochemical signature.

The present work aims to provide an update on the current state of knowledge on the different types of gold deposits models and their mode of formation. Section one 1) introduce us to the paper; section two 2) describe the major Periods of Gold formation; while sectionthree 3) and four 4) describe the main types of gold deposits and shows that the deposits can be formed in a wide variety of geodynamic contexts with each deposit type formed in a very particular context that meets all the conditions favourable for its formation; and section five 5) is the conclusion part of this paper.

\section{Major Gold Formation Periods}

Gold deposits were not consistently formed over geological time (Figure 2). The Mesoarchean was the largest gold period (representing approximately 90,000 tonnes of gold) from of a single deposit: paleoplacers of the Witwatersrand in South Africa. Other gold peaks followed, particularly in the Neoarchean, Paleoproterozoic and Paleozoic. These are dominated by orogenic gold deposits that were put in place during the major orogenies [13]. Numerous and diverse gold deposit types formed during the Cenozoic era include epithermal, porphyry, skarn and Carlin-type deposits. However, this distribution is based on the duration of preservation of certain types of deposits. In effect, the surficial deposits (e.g. porphyry and epithermal deposits) are more susceptible to erosion and eventually disappear. Thus, the gold period observed in the Cenozoic is artificially amplified with respect to older periods which are minimized.

The study of the spatial distribution of known gold deposits has led to the assumption that most of the gold in the continental crust would have been formed during a major gold event in the Mesoarchean, around $3 \mathrm{Ga}$ (Figure 2; [3]). The 


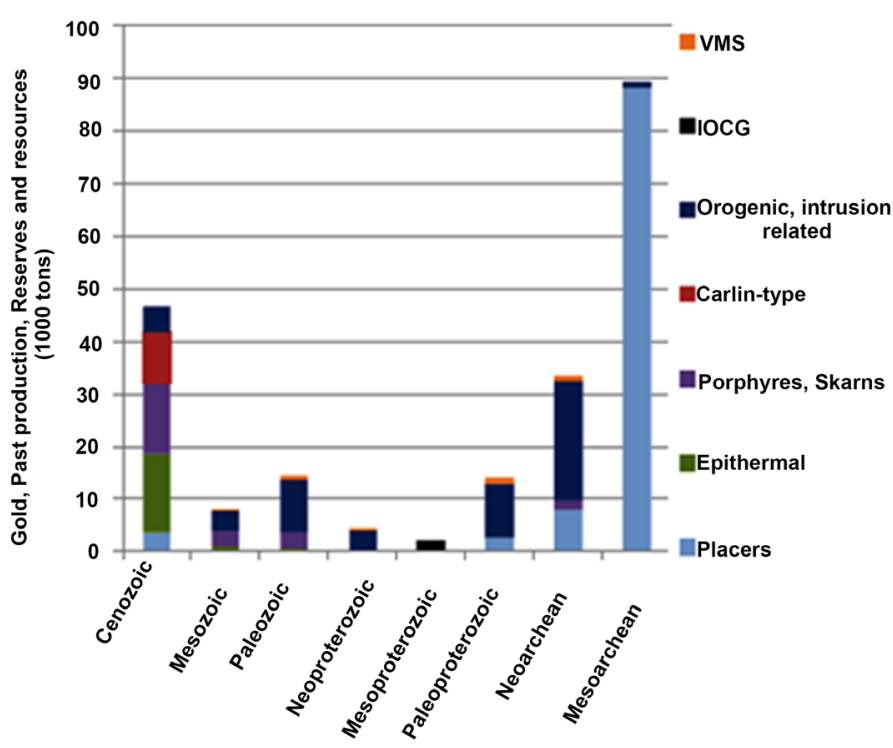

Figure 2. Distribution of different types of known gold deposit in geological time [3].

Witwatersrand gold deposit, which is the largest known deposit, is an argument for the existence of such a gold event in the Mesoarchean. The gold in the Witwatersrand basin has very high concentrations of Osmium and Rhenium than most of the other gold deposits. In addition, Re/Os and ${ }^{187} \mathrm{Os} /{ }^{188} \mathrm{Os}$ ratios of gold are similar to those known for the mantle $3 \mathrm{Ga}$ ago [14] [15] [16] indicating a magmatic origin. Contrarily, the depletion of osmium in subsequent deposits seems to be the result of remobilization of gold by hydrothermal fluids in which osmium is less soluble [17] (Figure 2).

The introduction of a large amount of gold into the crust during the Mesoarchean to form the Witwatersrand deposit can be explained in several ways. The first hypothesis attributes this gold supply to intense meteorite bombardment which took place after the differentiation of the core and the Earth's mantle about $3.2 \mathrm{Ga}$ [18]. The gold content of chondrites is about $140 \mathrm{ppb}$ [1]; an extraterrestrial supply would have significantly increased the content of the crust and mantle. However, recent gold metal-silicate partition coefficient calculations showed that an external supply was not needed to explain the gold contents of the mantle [19]. The Mesoarchean gold event can also be explained by a change in the thermal properties of the mantle during this period. It has been shown that the temperature of the mantle peaked $\left(250^{\circ} \mathrm{C}\right.$ higher than the current temperature) at $3 \mathrm{Ga}$ [20]. This temperature peak favoured the formation of mantle plumes which acted as vectors of transport of gold from the core-mantle discontinuity where it is enriched to the lithosphere [3].

\section{Types of Gold Deposits and Their Formation Conditions}

There are several types of gold deposits, with each type differing in geometry; nature of their host rocks; the form of mineralization; and/or the nature of min- 
erals associated with the mineralization. Each of these deposits are involved in varying proportions in world gold production, with the most prolific deposits being placer and orogenic gold, followed by porphyry and epithermal deposits (Figure 3).

Gold deposits can be classified by the nature of the host rock, the genetic model and on the mineral associations related to mineralization. Classification of deposits on the basis of mineralizing process into three main geological settings of formations viz; magmatic, hydrothermal and sedimentation is described here (Figure 3).

\subsection{Deposits of Magmatic-Hydrothermal Origin}

Interactions between igneous and hydrothermal processes play an important role in the formation of certain types of ore deposits, and more particularly in the sub-surface context.

\subsubsection{Porphyry Deposits}

Porphyry deposits are hydrothermal deposits associated with felsic to intermediate magma intrusions and they make up the largest gold reservoirs deposit in the Earth's crust ([1] [12]). This type of deposit is characterized by low to medium metal contents, but very high tonnages ([7] [21]). Porphyries occur at shallow depth (1 to $5 \mathrm{~km}$ ), around calc-alkalic intrusions related to subduction zones, island arcs or continental Cordilleras [22]. Main metals in this type of deposit are copper, molybdenum and gold.

Mineralization occurs in various forms, mainly associated with discordant structures: stockworks; fractures; faults, but it can also be disseminated in the host rock. $\mathrm{Cu}$-Au porphyrys are marked by very specific alterations that provide very important guides in prospecting. These alterations of hydrothermal origin are concentric around the centre of the intrusion ([7] [21]). The age of the porphyry deposits range from Archean to the present, even though the vast majority are upper Jurassic ([7] [21] [22]). Porphyry deposits are very susceptible to

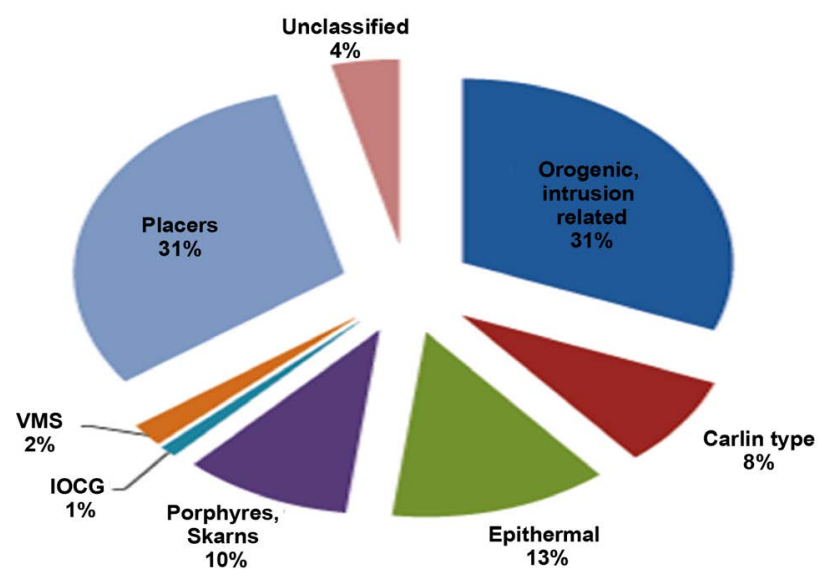

Figure 3. Relative Importance of the different types of gold deposit in overall production between 1984 and 2006 [3]. 
erosion as they are shallow, this is why their distribution is essentially limited to the most recent mountain chains (Figure 2), and the oldest have been eroded.

The formation of porphyry deposit depends on the formation of hybrid magma (of mantle and crustal sources) during subduction. The plunging plate is dehydrated, which causes partial melting of the overlapping plate. The magma goes up with the balance of the overlying crust and causes in its turn a fusion of its base. The calc-alkaline magma ascends to the surface through the crust via dykes to supply batholiths at lesser depth. Two phenomena will then intervene, contributing to the separation of aqueous fluid phase of the magma. Firstly, the ascent of the magma along the dykes is accompanied by a pressure drop that will decrease the solubility of water. On the other hand, the gradual crystallization of the magma will increase the water content of the residual liquid until it reaches threshold solubility [23]. The combination of these two processes will be at the origin of the different phases. Thus, the liberated fluid phase causes a hydraulic fracturing of the host rock, within the stockworks leading to mineralisation.

\subsubsection{Epithermal Deposits}

The epithermal deposits occur in the same tectonic settings relative to porphyry deposits, which are volcano-plutonic arcs, island arcs and Cordillera arcs associated with subduction zones. They are mainly present along the pacific ring and the alpine chain in Europe. They are very superficial deposits since they are deposited between $2 \mathrm{~km}$ depth and surface [24]. They are therefore very sensitive to erosion, which explains why most of the deposits still existing today are post Jurassic (Figure 2).

There are two types of epithermal deposits which are distinguished primarily by the difference in oxidation state of sulphur in the related ore-forming fluids [25]: we have "high sulfidation" deposits (also called acid epithermal) and "low sulfidation" deposits (neutral epithermal). The "high sulfidation" epithermal deposits form at temperatures between $150^{\circ} \mathrm{C}$ and about $300^{\circ} \mathrm{C}$ [24] from a very acidic mineralizing fluid. The mineralization is characterized by copper minerals, in particular the chalcopyrite, enargite and luzonite. This type of deposit is also very rich in pyrite; it's the most common sulphide. These deposits are hosted in volcanic andesitic to dacitic rocks belonging to the calc-alkaline series. Like porphyry deposits, the "high sulfidation" epithermal deposits are marked by zonation [24].

Unlike the acidic epithermal deposits, "low sulfidation" deposits have the particularity of being associated with hydrothermal fluids of neutral $\mathrm{pH}$ with temperature not exceeding $300^{\circ} \mathrm{C}$. These fluids are dominated by meteoric waters, but there is also evidence of the contribution of magmatic fluids and gases ([23] [26]). These deposits have varied textures: different generations of breccias, banded quartz, and chalcedony or calcite veins. The host rocks are magmatic or volcano-sedimentary, generally of calc-alkaline composition similar to high sulphidation epithermal deposits. Mineralization is essentially in the form of veins and stockwerks, even though it can be disseminated ([24] [25]). The mineralogy 
of such deposits is dominated by pyrite but sphalerite, galena, arsenopyrite, chalcopyrite and tellurides are equally found. The circulation of hydrothermal fluids is the origin of alteration zones, zoning is less marked compared to acidic epithermal deposits.

There is evidence showing the existence of a genetic and spatial link between porphyry and high sulfidation epithermal deposits, these latter constitutes the apex of porphyry systems [25]. The link between porphyry and low sulfidation epithermal deposits is less obvious. Indeed, unlike acid epithermal, low sulphide deposits do not occur in the immediate vicinity of a volcanic system but rather within geothermal systems. The formation acid epithermal deposits results from the release of vapours and magmatic fluids carrying metals during hydraulic fracturing around the porphyry, which will migrate to the surface [27]. The deposition of the mineralization will be caused either by a phenomenon of ebullition at the surface, a mixture and a dilution of the magmatic fluid by meteoric fluids, or a combination of these two phenomena ([27] [28]).

Hydrothermal fluids related to low sulphide epithermal deposits are a mixture between magmatic fluids and meteoric waters, with the latter being dominant. These fluids are less salty, thus poor in chlorine but particularly rich in gases $\left(\mathrm{H}_{2} \mathrm{~S}\right.$ and $\left.\mathrm{CO}_{2}\right)$. Under surface conditions, the fluids will enter into ebullition, phenomenon that will be accompanied by the loss of steam containing $\mathrm{CO}_{2}$ and $\mathrm{H}_{2} \mathrm{~S}$ [24]. This loss of sulphur will decrease the solubility of gold in the fluid provoking its precipitation along the fluid's circulation path.

\subsubsection{Skarns}

Skarns deposits result from the interaction of hydrothermal fluids from silicate magma (mostly dioritic to granitic in composition) with host sedimentary rocks ([29] [30] [31]). They occur close to magmatic intrusions within orogenic belts and their temporal distribution spans from Precambrian to tertiary, though most exploited deposits are relatively young. Gold is present in many skarn as a by-product of base metal $(\mathrm{Cu}, \mathrm{Fe}, \mathrm{Pb}, \mathrm{Zn})$, Tin and tungsten deposits, but skarn deposits exclusively exploited for gold exist. These gold skarns have a Calc-silicate metasomatic alteration due to contact metamorphism, dominated by garnet, pyroxene, related to gold mineralization ([29] [32]). It is the main feature of this type of deposit. While skarn deposits can form varied geological environments, gold skarns occur preferentially around magmatic arcs associated with subduction of continental crust or around back-arc basins.

Skarns are formed in three stages ([32] [33]). 1) During emplacement of the intrusion, host rocks dehydrate and expel fluids that will alter the surrounding limestone into marble. 2) The pluton releases magmatic fluids at high temperature $\left(500^{\circ} \mathrm{C}\right.$ to $\left.600^{\circ} \mathrm{C}\right)$ which is at the origin of a prograde [34] metasomatism, accompanied by the formation of metamorphic typical skarn minerals (notably pyroxenes and garnets). 3) Finally, the retrograde hydrothermal stage corresponds to a drop in fluid temperature $\left(300^{\circ} \mathrm{C}\right.$ to $450^{\circ} \mathrm{C}$ ) and water supply (potentially via meteoric fluids) that will lead to the formation of hydrated minerals 
such as amphibole. It is also during this final stage that metals are deposited in native form or as sulphides. Skarn mineralogy is highly variable and depends on the nature of the intrusion as well as the composition of host rocks [32].

\subsubsection{Iron-Oxide-Copper-Gold (IOCG) Deposits}

IOCG deposits (or iron-oxide deposits) recently appeared in the classification of metal deposits and still remains quite poorly defined. IOCG deposits are characterized by their abundance in iron oxides (magnetite or hematite), phosphorus, fluorine, barium and rare earths, and their low titanium content ([34] [35]). These deposits are mainly exploited for copper and gold. Main IOCG deposits range from Archean to Mesozoic and are found in Australia (e.g. Olympic Dam, Prominent Hill) and South America. These deposits are formed by extensive context along major structures and their geometry tends to follow the local or regional deformations [34].

The origin of IOCG deposits is under debate, particularly concerning the nature of mineralizing fluids involved. Views differ between magmatic brine ([34] [35]) and external brine set in motion by intrusions [36] as mineralizing fluid. However, a study of IOCG in the Central Andes [37] favours a magmatic origin for fluids as well as the source of gold, although other types of fluids (metamorphic, sea or connate water) can intervene locally. In all cases, the fluids are oxidizing, have high temperature (up to $600^{\circ} \mathrm{C},[34]$ ) and high salinity. The mineral deposition seems to depend on structural control. It occurs along faults or shear zones, lithostratiqraphic contacts, or around contacts between granitoids and their host rocks [35]. IOCG are not systematically formed close to intrusive bodies, however, several arguments indicate a genetic link between mineralization and magmas, particularly alkaline magmas.

\subsubsection{Intrusion-Related Deposits}

In the broad sense, deposits related to a magmatic intrusion ("intrusion-related deposits" or "intrusion-related systems") may include the four types of deposits described above ([34] [38]). In a more restricted definition, this term designates the deposits that form outside the areas of formation of porphyry, preferentially in continental domain [32]. These deposits are characterized by a mineralization spatially associated with reduced magmatic intrusions with metaluminous, granitic to granodioritic composition of crustal origin ([32] [34] [38] [39] [40]).

They are distinguished from $\mathrm{Au} \pm \mathrm{Cu}$ porphyry deposits by the lack of base metals, a very low oxidation state and a low sulphide content ([28] [34]). Gold mineralization is often accompanied by $\mathrm{Bi}, \mathrm{W}, \mathrm{As}, \mathrm{Mo}, \mathrm{Ag}, \mathrm{Sn}, \mathrm{Te}, \mathrm{Sb}$ occurrences ([34] [38]). These deposits were essentially formed throughout the Phanerozoic, however, there are some examples of gold deposits related to intrusions dating from Proterozoic to Archean (e.g. [40]). This type of deposit is particularly present in Alaska and the Yukon, Canada ([34] [39]).

\subsection{Deposits of Hydrothermal Origin}

The term "hydrothermal deposits" refers to deposits whose formation depends 
mainly on the circulation of hydrothermal fluids other than magmatic fluids (metamorphic fluids, meteoric water, sea water, connate waters...) in the crust. These deposits may be associated with magmatic intrusions like the previous deposits, but in this case, the intrusion is only a heat engine of fluid circulations.

\subsubsection{Orogenic Gold Deposits}

Orogenic gold deposits, also called mesothermal gold deposits are of great economic importance as they represent about $30 \%$ of World gold production (Figure 3). Unlike most deposits, orogenic gold deposits are formed late in the evolution of convergent margin environments during the major orogenic events ([13] [22] [41]), and are syn to post metamorphic. They formed in an episodic manner from mid-Archean to Proterozoic, then more evenly throughout the Phanerozoic (Figure 4) [13].

The formation of orogenic gold deposits is closely associated with the tectono-thermal events during orogenies. As such, these deposits are hosted in metamorphosed rocks, most often in the greenschist facies. Metamorphic fluids released by rocks during dehydration reactions during prograde metamorphism form regional hydrothermal systems ([13] [41]). It concerns aqueous-carbonic fluids of low salinity [42]. The origin of gold appears to be both due to these metamorphic fluids and it's leaching by rocks they circulate through [43]. These gold-bearing fluids are then channeled through major discontinuities along which the reaction of fluids with the host rocks is going to be at the origin of lateral zones of alteration that can extend over several meters [41].

The deposition of the mineralization takes place during the destabilization of the gold bearing sulphide complexes in solution. This destabilization is followed by the cooling of hydrothermal fluids, a change in redox conditions, or a change in $\mathrm{pH}$ [42]. Several factors can cause chemical changes in fluids including the existence of large scale pressure and temperature gradients; interactions between fluids and host rocks; pressure fluctuations; or a mixture of fluids (e.g. with meteoric waters).

Gold bearing mineralization generally occur as veins (hence the name of "lode deposits") associated to second order structures (or more), near major structures of accretion ([13] [35] [41] [42]). The mineralogy of these veins is dominated by the quartz, accompanied by a small proportion of sulphides (primarily of iron sulphides) and carbonate minerals. The gold contents are relatively high, about 5 to $30 \mathrm{~g} / \mathrm{t} \mathrm{[41]} \mathrm{and} \mathrm{the} \mathrm{Au} / \mathrm{Ag}$ ratio varies between 1 and 10 . The orogenetic gold deposits can be formed at depths reaching $25 \mathrm{~km}$ or more, this is why many were preserved throughout geologic time ([13] [22] [35] [41]) (Figure 4).

\subsubsection{Volcanogenic Massive Sulfide (VMS) Deposits}

Hydrothermal circulation in the ocean crust can be at the origin of the formation of ore deposits: volcanogenic massive sulphide (VMS). VMS are stratiform ore bodies formed from hydrothermal fluids in the seafloor in association with volcanic rocks [44]. This type of deposit is formed in varied tectonic settings 


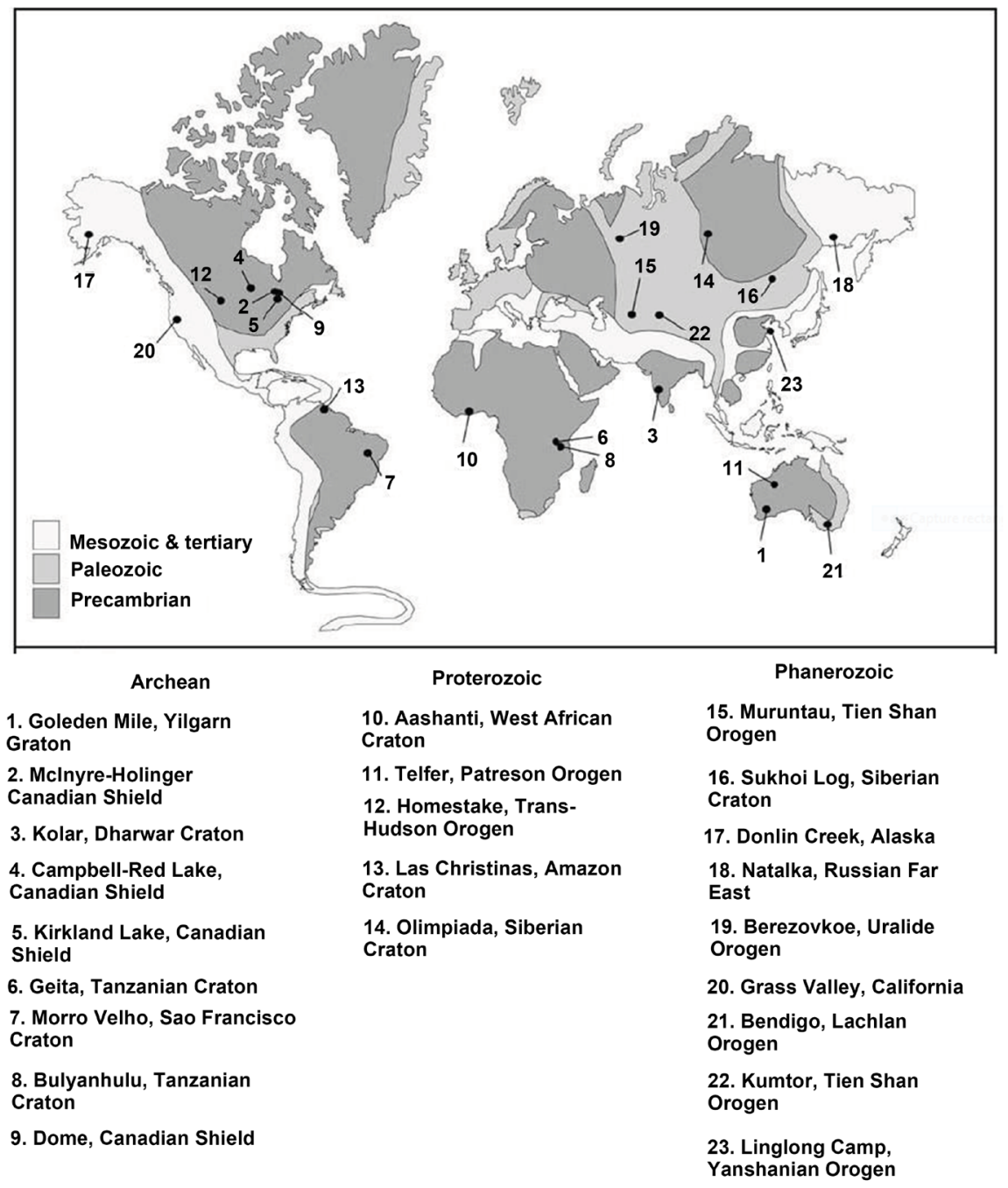

Figure 4. Global Distribution of Precambrian, Paleozoic, Mesozoic and Cenozoicterrains with the location of the 23 largest orogenic gold deposits [5].

such as oceanic ridges, arcs and oceanic rifts ([45] [46]) but also in back-arc basins, in volcanic and volcano-sedimentary sequences from Archean to present. The mineralogy of these deposits is dominated by iron sulphides notably pyrite and pyrrhotite which generally predominate, but chalcopyrite, sphalerite or galena are also present.

VMS are formed following the circulation of sea water contained in pores or faults in the rocks of the seafloor, via shallow mafic to felsic magmatic intrusion. The heat generated by the intrusion creates a convective hydrothermal system in which seawater is heated to $400^{\circ} \mathrm{C}$ and mixed with magmatic fluids leach metals from the surrounding volcanic and/or sedimentary rocks. The hydrothermal fluid rapidly cools in contact with the cold sea water causing a decrease in the solubility of metals and their precipitation. Sulphide precipitates around the hydrothermal vents forming chimneys of several meters in height which eventually collapse to form tabular or lenticular ore bodies [45]. 
There are different subtypes of VMS deposits based on the composition of the host volcanic series and thus the geodynamic context of their formation. VMS are characterized by their small size (with few exceptions) but with very high metal content that makes them attractive for mining. They are primarily mined for copper, zinc and lead but some of them contain significant amounts of gold or silver. Gold rich VMS deposits usually differ from the gold poor VMS deposits in the same district by several features (composition of volcanic rocks, alteration assemblages, trace element signatures...) which reflect local geological control of gold enrichment ([47] [48]).

\subsubsection{Carlin-Type Deposits}

The Carlin-type gold deposits make up the largest hydrothermal gold deposits in the world, they take their name from the Carlin deposit discovered in Nevada in the 1960s. They share many similarities with the orogenic gold deposits but, unlike the latter, they are formed during extensive regimes that follow the subduction processes [49]. They are deposits hosted in sedimentary rocks, with the disseminated gold mineralization localised in arsenic pyrites, and characterized by enrichment of As, $\mathrm{Sb}, \mathrm{Hg}$ and $\mathrm{Tl}$, and low base metal content [50]. They have high tonnage which enables exploitation even at low grades. These deposits were put in place within structural traps (faults, folds...) or lithological traps such as the interface between a carbonate platform and siliciclastic rocks [51], at a depth of 1 to $4 \mathrm{~km}$ [52].

The model of formation of Carlin type deposits is not well understood, and the source of metals remains controversial as well as the nature of hydrothermal fluids that carry them [53]. Meteoric, magmatic, metamorphic fluids and basins were in turn proposed. Following the study of the isotopic composition of sulphur in a deposit in Nevada, [53] deduced that the mineralizing fluids are essentially of magmatic origin. However, this hypothesis seems hardly compatible with the general characteristics of the fluid inclusions indicating low salinity ( 1 to $8 \mathrm{wt} \%$ eq. $\mathrm{NaCl})$ and low temperature $\left(150^{\circ} \mathrm{C}\right.$ to $\left.250^{\circ} \mathrm{C},[54]\right)$. On the other hand, a magmatic origin of fluids cannot be considered for the districts devoid of intrusions as is the case in China [54]. The tendency would therefore be to consider meteoric fluids as mineralizing fluids for this type of deposit or a mixture of different types of fluids.

The mineralization of the Carlin-type deposits is represented by sub-micrometric gold grains found usually in the Crystal structure of disseminated pyrite accompanied by arseno-pyrite, or in arsenic-enriched pyrite overgrowths ([49] [51]). Hydrothermal circulation at the origin of the mineralization is accompanied by alteration of country rocks consisting of silicification, a decarbonation or dissolution of calcite and dolomite [51]. These transformations have consequently increased porosity and permeability of the rock, which promotes the migration of hydrothermal fluids. These fluid-rock alterations, accompanied or not by a dilution of fluids by mixing, which cause the destabilization of the sulphide complexes and therefore the deposit of gold [35]. 


\subsection{Deposits of Sedimentary origin: Placers}

Hydrothermal processes (whether or not related to magmatic processes) are at the origin of the formation of the majority of gold deposits on earth. However, some sedimentary processes can also lead to deposits of economic importance such as placer gold. Placers are typically secondary deposits that require remobilization from a source reservoir, transportation and then re-sedimentation at a concentration site [55]. A placer is defined as an accumulation of dense detrital minerals during the sedimentary deposition. Placer deposits are widespread, found particularly in Russia, Brazil, Canada, China, and Alaska. Two major types of placers can be distinguished based on their period of formation: neo-placers formed between the Eocene and Quaternary, and paleoplacers which represent the majority of the exploited Placers.

Gold mineralization in paleoplacers occurs in conglomerates, probably of fluvial origin, rich in quartz. The most representative of deposits of this type in terms of size is the Witwatersrand deposit in South Africa ([56] [57] [58] [59]), the Tarkwa deposit in Ghana ([33] [60] [61] [62]) and the Jacobina deposit in Brazil [63]. The Archean Witwatersrand deposit is probably the best-known paleoplacer since it dominates global gold production. However, debates have long persisted about the nature of this deposit and hypotheses are shared between a hydrothermal origin of the mineralization that may have formed long after the host sedimentary deposition [58] and a detrital origin [64] with one placer model ([36] [56]), or a placer model modified by subsequent hydrothermal events [65]. Re-Os data indicate an age of the gold grains prior to the age of the sedimentary basin, most recent studies argue for a detrital model without excluding minor hydrothermal contribution ([14] [59] [66] [67]). One of the main problems in the study of paleoplacers is to identify the source of the gold. The source of some placers located in the Pacific belt [68], Russia [69] or Australia [13] has been attributed to existing orogenic gold deposits, but in most cases the source of deposits have disappeared, which further complicates their identification.

\section{Geodynamics and Formation of Gold Deposits}

There is a wide variety of gold deposits that differ by their geology and also by their mode of formation. The description of the main types of gold deposits in the preceding paragraphs shows that the gold deposits can be formed in a wide variety of geodynamic contexts. In addition, each type of deposit is formed in a very particular context (Figure 5) and meets all the conditions favourable for its formation. Gold deposits are thus markers of the geological events that led to their formation, and other than its purely economic aspect, their study enables the study of these events (Figure 5).

It is noted that among the different contexts that can lead to the formation of a gold deposit, active margins, and in particular the subduction zones, are the most effective as they host the largest epigenetic gold deposits which include: 


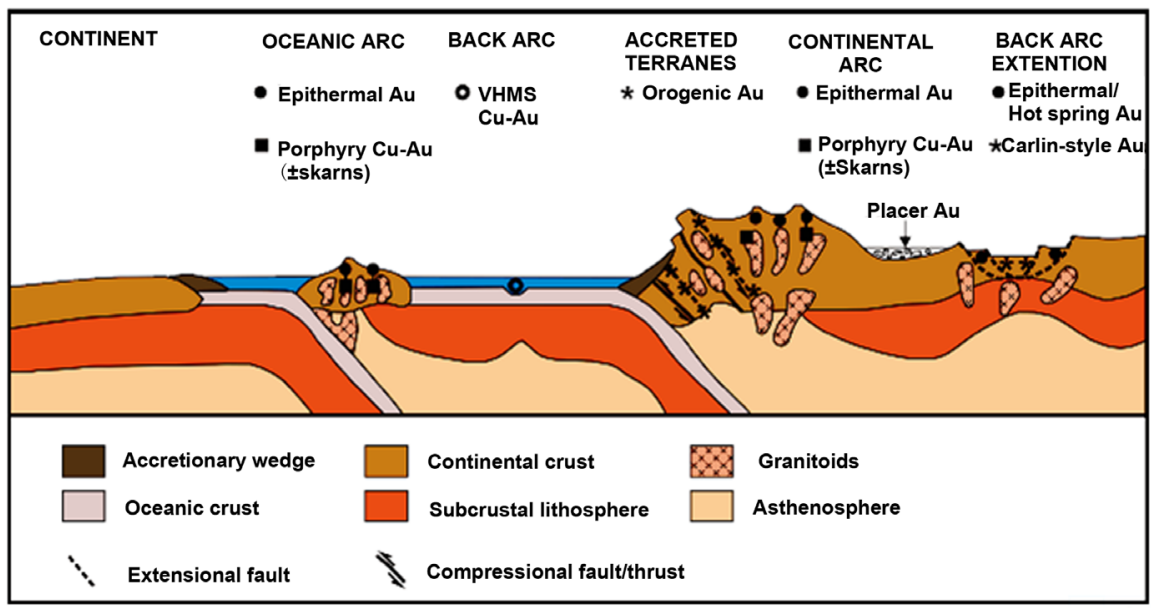

Figure 5. Sketch illustration of the tectonic setting of the most common gold deposit types. After [41] [70].

orogenic gold deposits, porphyry and epithermal deposits ([3] [41] [70]).

The concentration of gold in these deposits is controlled by a combination of several geological factors including the nature of the crust as well as the thickness of lithospheric plate. [6] noted that huge orogenic gold deposits are more likely to form in an orogeny involving the subduction of the oceanic lithosphere (slightly richer gold than the continental lithosphere) where the thin continental lithosphere facilitates the circulation of fluids.

The geodynamic processes controlling the formation of a deposit will also affect the depth of emplacement. Thus, sedimentary deposits such as Placers systematically form at the surface while hydrothermal and magmatic deposits can be emplaced at different levels within the crust (Figure 6). Most of these deposits occur within $5 \mathrm{~km}$ of depth, except orogenic golddeposits which occur further (from 5 to more than $25 \mathrm{~km}$ of depth). This difference explains the better preservation of orogenic deposits over geological time (Figure 6).

The largest gold deposits (except Placers) thus formed during periods of crustal growth as shown in Figure 7 are orogenic deposits. These periods of accretion are the seat of important exchanges between the mantle and the crust and are accompanied by heat flows favoring the circulation of fluids ([5] [6] [13]). The study and understanding of the formation of gold deposits therefore indirectly enable the study of these exchanges (Figure 7).

\section{Conclusions}

Earlier it has been argued that gold deposits, by their diversity, are markers of geodynamic events. The study of their formation makes it possible to understand the interactions between the metallogenic and geodynamic processes within a region. This study provides a significant progress in the understanding of the variety of gold deposits that differ by their geology and also by their mode of formation. 


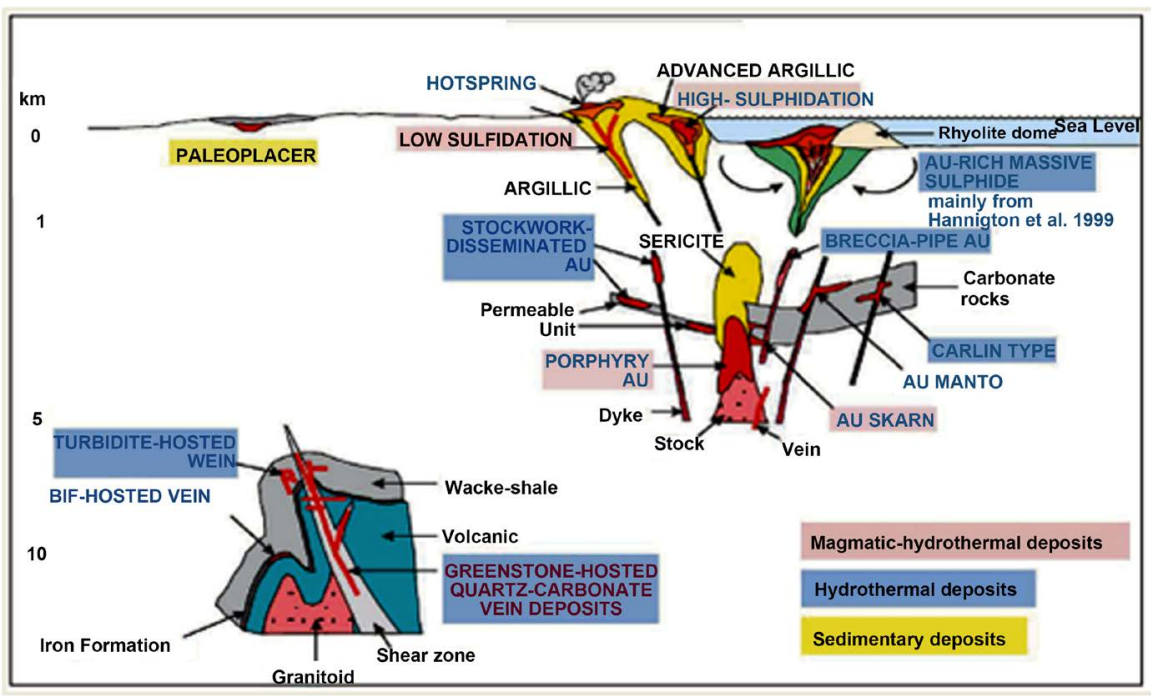

Figure 6. Distribution of the different types of gold deposits within a segment of crust (modified from [71].

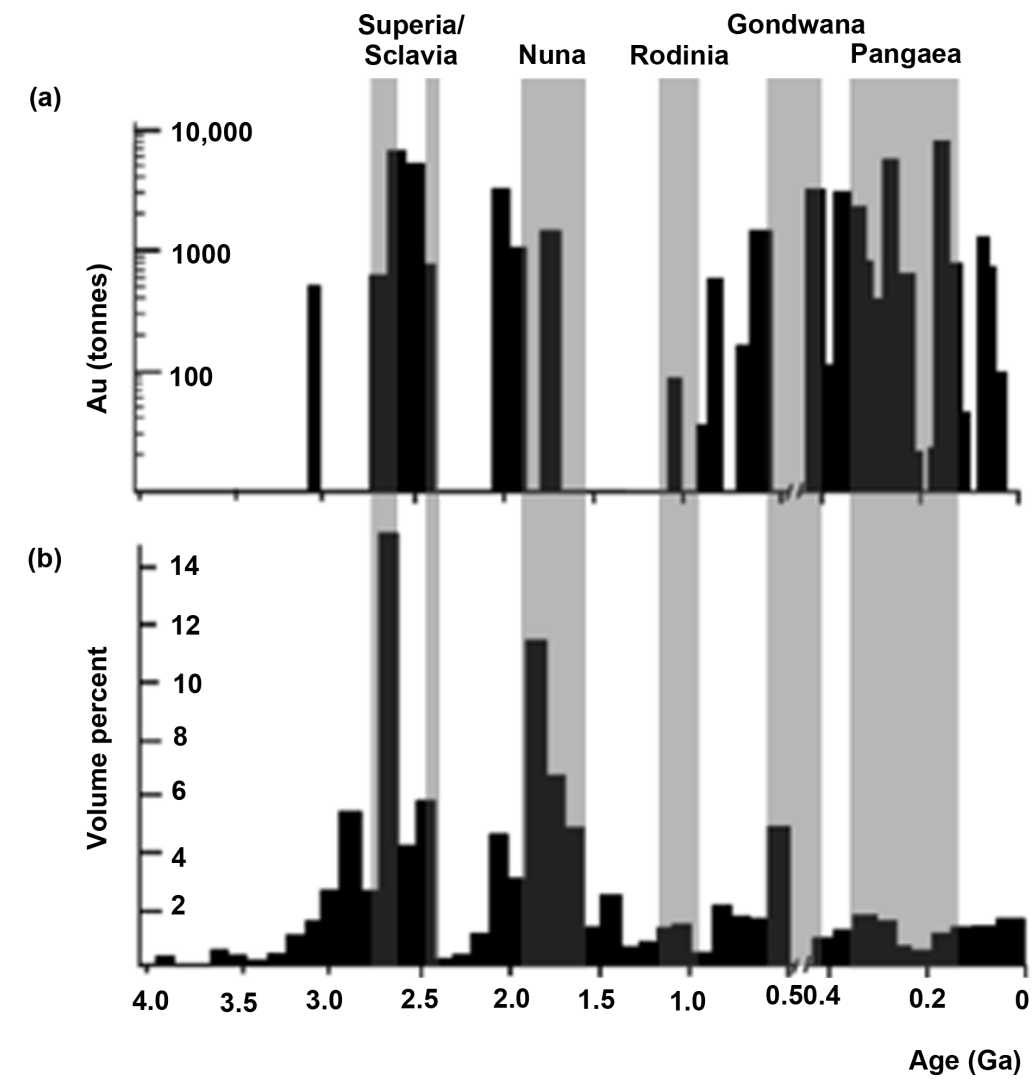

Figure 7. (a) Distribution of orogenic gold deposits; (b) Evolution of the growth of the continental crust over geologic time (modified after [5] [72]). The grey bands represent the distribution of the supercontinents after [73].

To date the literature noted that among the different contexts that can lead to the formation of a gold deposit, active margins, and in particular the subduction zones, are the most effective as they host the largest epigenetic gold deposits 
which include: orogenic gold deposits, porphyry and epithermal deposits. This study affirms that the concentration of gold in the deposits is controlled by a combination of several geological factors including the nature of the crust as well as the thickness of lithospheric plate.

While this study does not offer a conclusive answer, the research raises important questions about the state of knowledge on the different types of gold deposits models, geodynamics, their mode of formation and the condition suitable for their formation.

As a result of conducting this research, I propose that, if policymakers were to take this study seriously, they might be better equipped than ever to face the increasingly difficult challenge of finding gold.

\section{Acknowledgements}

The authors are grateful to Prof. Anthony Azubuike Elueze, Prof. Yongue Fouateu Rose and Prof. Bolarinwa Anthony Temidayo for providing relevant information on this research paper. This paper is a part of the first author's Ph.D. thesis at the Pan African University Life and Earth Science Institute. We also thank reviewers for constructive comments that helped to improve an earlier manuscript version. The Ph.D. programme of Mr. Nguimatsia Dongmo Franck Wilfried is being funded by African Union through Pan African University, Institute of Life and Earth Sciences (including Health and Agriculture),University of Ibadan, Nigeria. We are grateful to all organizations who granted financial support for this intended work. Reviewers are highly appreciated.

\section{References}

[1] McDonough, W.F. and Sun, S.-S. (1995) The Composition of the Earth. Chemical Geology, 120, 223-253. https://doi.org/10.1016/0009-2541(94)00140-4

[2] Wood, B.J., Walter, M.J. and Wade, J. (2006) Accretion of the Earth and Segregation of Its Core. Nature, 441, 825-833. https://doi.org/10.1038/nature04763

[3] Frimmel, H.E. (2008) Earth's Continental Crustal Gold Endowment. Earth and Planetary Science Letters, 267, 45-55. https://doi.org/10.1016/j.epsl.2007.11.022

[4] Rudnick, R.L. and Gao, S. (2003) Composition of the Continental Crust. In: Rudnick, R.L., Ed., Treatise on Geochemistry, Elsevier, Amsterdam, 1-64. https://doi.org/10.1016/B0-08-043751-6/03016-4

[5] Bierlein, F.P., Groves, D.I., Goldfarb, R.J. and Dubé, B. (2006a) Lithospheric Controls on the Formation of Provinces Hosting Giant Orogenic Gold Deposits. Mineralium Deposita, 40, 874-886. https://doi.org/10.1007/s00126-005-0046-2

[6] Bierlein, F.P., Stein, H.J., Coira, B. and Reynolds, P. (2006b) Timing of Gold and Crustal Evolution of the Palaeozoic South Central Andes, NW Argentina-Implications for the Endowment of Orogenic Belts. Earth and Planetary Science Letters, 245, 702-721. https://doi.org/10.1016/j.epsl.2006.03.019

[7] Sillitoe, R.H. (2010) Porphyry Copper Systems. Economic Geology, 105, 3-41. https://doi.org/10.2113/gsecongeo.105.1.3

[8] Bonham, H.F.J. (1989) Bulk Mineable Gold Deposits of the Western United States. 
In: Keays, R.R., Ramsay, W.R.H. and D.I., Eds., The Geology of Gold Deposits. The Perspective in 1988, Monograph 6, Economic Geology, 193-207.

[9] Heald, P., Foley, N.K. and Hayba, D.O. (1987) Comparative Anatomy of Volcanichosted Epithermal Deposits: Acid-Sulphate and Adularia-Sericite Types. Economic Geology, 82, 1-26. https://doi.org/10.2113/gsecongeo.82.1.1

[10] Gebre-Mariam, M., Hagemann, S.G. and Groves, D.I. (1995) A Classification Scheme for Epigenetic Archean Lode-Gold Deposits. Mineralium Deposita, 30, 408-410. https://doi.org/10.1007/BF00202283

[11] Robert, F., Poulsen, K.H. and Dubé, B. (1997) Gold Deposits and Their Geological Classification. Gubins A.G., Ed., Proceedings of Exploration 97: Fourth Decennial International Conference on Mineral Exploration, 209-220.

[12] Le Mignot, E. (2014) Gold Deposits as Witnesses of History Geological Survey of the West African Craton-Contribution of Dating. Doctoral Thesis, University of Lorraine (Nancy), Lorraine, 339 p.

[13] Goldfarb, R.J., Groves, D.I. and Gardoll, S. (2001) Orogenic Gold and Geologic Time: A Global Synthesis. Ore Geology Reviews, 18, 1-75. https://doi.org/10.1016/S0169-1368(01)00016-6

[14] Kirk, J., Ruiz, J., Chesley, J., Titley, S. and Walshe, J. (2001) A Detrital Model for the Origin of Gold and Sulfides in the Witwatersrand Basin Based on Re-Os Isotopes. Geochimica et Cosmochimica Acta, 65, 2149-2159. https://doi.org/10.1016/S0016-7037(01)00588-9

[15] Kirk, J., Ruiz, J., Chesley, J., Walshe, J. and England, G. (2002) A Major Archean, Goldand Crust-Forming Event in the Kaapvaal Craton, South Africa. Science, 297, 1856-1858. https://doi.org/10.1126/science.1075270

[16] Frimmel, H.E., Groves, D.I., Kirk, J., Ruiz, J., Chesley, J. and Minter, W.E.L. (2005) The Formation and Preservation of the Witwatersrand Goldfields, the World's Largest Gold Province. Economic Geology, 100, 769-797.

[17] Xiong, Y. and Wood, S.A. (2000) Experimental Quantification of Hydrothermal Solubility of Platinum-Group Elements with Special Reference to Porphyry Copper Environments. Mineralogy and Petrology, 68, 1-28. https://doi.org/10.1007/s007100050001

[18] Glikson, A.Y. (2001) The Astronomical Connection of Terrestrial Evolution: Crustal Effects of Post-3.8 Ga Mega-Impact Clusters and Evidence for Major $3.2 \pm 0.1$ Ga Bombardment of the Earth-Moon System. Journal of Geodynamics, 32, 205-229. https://doi.org/10.1016/S0264-3707(01)00029-1

[19] Brenan, J.M., McDonough, W.F. and Ash, R. (2005) An Experimental Study of the Solubility and Partitioning of Iridium, Osmium and Gold between Olivine and Silicate Melt. Earth and Planetary Science Letters, 237, 855-872. https://doi.org/10.1016/j.epsl.2005.06.051

[20] Labrosse, S. and Jaupart, C. (2007) Thermal Evolution of the Earth: Secular Changes and Fluctuations of Plate Characteristics. Earth and Planetary Science Letters, 260, 465-481. https://doi.org/10.1016/j.epsl.2007.05.046

[21] Sinclair, W.D. (2007) Porphyry Deposits. In: Goodfellow, W.D., Ed., Mineral Deposits of Canada: A Synthesis of Major Deposit-Types, District Metallogeny, The Evolution of Geological Provinces, and Exploration Methods, Geological Association of Canada, 223-243.

[22] Bierlein, F.P., Groves, D.I. and Cawood, P.A. (2009) Metallogeny of Accretionary Orogens-The Connection between Lithospheric Processes and Metal Endowment. 
Ore Geology Reviews, 36, 282-292. https://doi.org/10.1016/j.oregeorev.2009.04.002

[23] Hedenquist, J.W. and Lowenstern, J.B. (1994) The Role of Magmas in the Formation of Hydrothermal Ore Deposits. Nature, 370, 519-527. https://doi.org/10.1038/370519a0

[24] White, N.C. and Hedenquist, J.W. (1995) Epithermal Gold Deposits: Styles, Characteristics and Exploration. SEG Newsletter, 23, 9-13.

[25] Hedenquist, J.W., Izawa, E., Arribas, A. and White, N.C. (1996) Epithermal Gold Deposits: Styles, Characteristics, and Exploration. Society of Resource Geology Ressource Geology Special Publication No. 1, 17 p.

[26] Simmons, S.F. (1995) Magmatic Contribution to Low-Sulfidation Epithermal Deposits. Mineralogical Association of Canada Short Course Series: Magmatic, Fluids, and Ore Deposits, 23, 455-477.

[27] Arribas, A. (1995) Characteristics of High-Sulfidation Epithermal Deposits, and Their Relation to Magmatic Fluids. Mineralogical Association of Canada Short Course Series: Magmatic, Fluids, and Ore Deposits, 23, 419-454.

[28] Henley, R.W. and Berger, B.R. (2011) Magmatic-Vapor Expansion and the Formation of High-Sulfidation Gold Deposits: Chemical Controls on Alteration and $\mathrm{Mi}$ neralization. Ore Geology Reviews, 39, 63-74. https://doi.org/10.1016/j.oregeorev.2010.11.003

[29] Einaudi, M.T. and Burt, D.M. (1982) Introduction; Terminology, Classification, and Composition of Skarn Deposits. Economic Geology, 77, 745-754. https://doi.org/10.2113/gsecongeo.77.4.745

[30] Meinert, L.D., Lentz, D.R. and Newberry, R.J. (2000) Special Issue Devoted to Skarn Deposits. Economic Geology, 95, 1183-1370. https://doi.org/10.2113/gsecongeo.95.6.1183

[31] Chen, Y.-J., Chen, H.-Y., Zaw, K., Pirajno, F. and Zhang, Z.-J. (2007) Geodynamic Settings and Tectonic Model of Skarn Gold Deposits in China: An Overview. Ore Geology Reviews, 31, 139-169. https://doi.org/10.1016/j.oregeorev.2005.01.001

[32] Dill, H.G. (2010) The "Chessboard" Classification Scheme of Mineral Deposits $\mu$ Mineralogy and Geology from Aluminum to Zirconium. Earth Science Reviews, 100, 1-420. https://doi.org/10.1016/j.earscirev.2009.10.011

[33] Pigois, J.-P., Groves, D.I., Fletcher, I.R., McNaughton, N.J. and Snee, L.W. (2003) Age Constraints on Tarkwaian Palaeoplacer and Lode-Gold Formation in the Tarkwa-Damang District, SW Ghana. Mineralium Deposita, 38, 695-714. https://doi.org/10.1007/s00126-003-0360-5

[34] Hitzman, M.W., Oreskes, N. and Einaudi, M.T. (1992) Geological Characteristics and Tectonic Setting of Proterozoic Iron Oxide (Cu-U-Au-REE) Deposits. Precambrian Research, 58, 241-287. https://doi.org/10.1016/0301-9268(92)90121-4

[35] Kerrich, R., Goldfarb, R., Groves, D., Garwin, S. and Jia, Y. (2000) The Characteristics, Origins, and Geodynamic Settings of Supergiant Gold Metallogenic Provinces. Science in China Series D: Earth Sciences, 43, 1-68. https://doi.org/10.1007/BF02911933

[36] Hitzman, M.W. (2000) Iron Oxide-Cu-Au Deposits: What, Where, When, and Why. In: Porter, T.M., Ed., Hydrothermal Iron Oxide Copper-Gold and Related Deposits. A Global Perspective, Australian Mineral Foundation, Adelaide, 9-25.

[37] Sillitoe, R.H. (2003) Iron Oxide-Copper-Gold Deposits: An Andean View. Mineralium Deposita, 38, 787-812. https://doi.org/10.1007/s00126-003-0379-7

[38] Thompson, J.F.H., Sillitoe, R.H., Baker, T., Lang, J.R. and Mortensen, J.K. (1999) 
Intrusionrelated Gold Deposits Associated with Tungsten-Tin Provinces. Mineralium Deposita, 34, 323-334. https://doi.org/10.1007/s001260050207

[39] Maloof, T.L., Baker, T. and Thompson, J.F. (2001) The Dublin Gulch Intrusion-Hosted Gold Deposit, Tombstone Plutonic Suite, Yukon Territory, Canada. Mineralium Deposita, 36, 583-593. https://doi.org/10.1007/s001260100190

[40] Hart, C.J.R. and Goldfarb, R.J. (2005) Distinguishing Intrusion-Related from Orogenic Gold Systems. New Zealand Minerals Conference Proceedings, Australasian Institute of Mining and Metallurgy, Melbourne, Victoria, 125-133.

[41] Groves, D.I., Goldfarb, R.J., Gebre-Mariam, M., Hagemann, S.G. and Robert, F. (1998) Orogenic Gold Deposits: A Proposed Classification in the Context of Their Crustal Distribution and Relationship to Other Gold Deposit Types. Ore Geology Reviews, 13, 7-27. https://doi.org/10.1016/S0169-1368(97)00012-7

[42] McCuaig, C. and Kerrich, R. (1998) P-T-t-Deformation-Fluid Characteristics of Lode Gold Deposits: Evidence from Alteration Systematics. Ore Geology Reviews, 12, 381-453. https://doi.org/10.1016/S0169-1368(98)00010-9

[43] Pitcairn, I.K., Craw, D. and Teagle, D.A.H. (2014) Metabasalts as Sources of Metals in Orogenic Gold Deposits. Mineralium Deposita, 1-18. [In Press]

[44] Herrington, R., Maslennikov, V., Zaykov, V., Seravkin, I., Kosarev, A., Buschmann, B., Orgeval, J.-J., Holland, N., Tesalina, S., Nimis, P., et al. (2005) 6: Classification of VMS Deposits: Lessons from the South Uralides. Ore Geology Reviews, 27, 203-237. https://doi.org/10.1016/j.oregeorev.2005.07.014

[45] Franklin, J.M., Gibson, H.L., Jonasson, I.R. and Galley, A.G. (2005) Volcanogenic Massive Sulfide Deposits. Economic Geology 100 th Anniversary Volume, 523-560.

[46] Hannington, M.D., de Ronde, C.E.J. and Petersen, S. (2005) Sea-Floor Tectonics and Submarine Hydrothermal Systems. Economic Geology 100 th Anniversary Volume, 111-141.

[47] Hannington, M.D., Poulsen, K.H., Thompson, J.F.H. and Sillitoe, R.H. (1999) Volcanogenic Gold in the Massive Sulfide Environment. In: Barrie, C.T. and Hannington, M.D., Eds., Volcanic-Associated Massive Sulfide Deposits. Processes and EXamples in Modern and Ancient Settings, GeoScienceWorld, 325-356.

[48] Mercier-Langevin, P., Hannington, M.D., Dubé, B. and Bécu, V. (2011) The Gold Content of Volcanogenic Massive Sulfide Deposits. Mineralium Deposita, 46, 509-539. https://doi.org/10.1007/s00126-010-0300-0

[49] Hofstra, A.H. and Cline, J.S. (2000) Characteristics and Models for Carlin-Type Gold deposits. In: Hagemann, S.G. and Brown, P.E., Eds., Gold in 2000, Society of Economic Geologists, 163-220.

[50] Emsbo, P., Groves, D.I., Hofstra, A.H. and Bierlein, F.P. (2006) The Giant Carlin Gold Province: A Protracted Interplay of Orogenic, Basinal, and Hydrothermal Processes above a Lithospheric Boundary. Mineralium Deposita, 41, 517-525. https://doi.org/10.1007/s00126-006-0085-3

[51] Peters, S.G. (2004) Syn-Deformational Features of Carlin-Type Au Deposits. Journal of Structural Geology, 26, 1007-1023. https://doi.org/10.1016/j.jsg.2003.11.018

[52] Kuehn, C.A. and Rose, A.W. (1995) Carlin Gold Deposits, Nevada; Origin in a Deep Zone of Mixing between Normally Pressured and Overpressured Fluids. Economic Geology, 90, 17-36. https://doi.org/10.2113/gsecongeo.90.1.17

[53] Kesler, S.E., Riciputi, L.C. and Ye, Z. (2005) Evidence for a Magmatic Origin for Carlin Type Gold Deposits: Isotopic Composition of Sulfur in the Betze-Post-Screamer Deposit, Nevada, USA. Mineralium Deposita, 40, 127-136. 
https://doi.org/10.1007/s00126-005-0477-9

[54] Rui-Zhong, H., Wen-Chao, S., Xian-Wu, B., Guang-Zhi, T. and Hofstra, A.H. (2002) Geology and Geochemistry of Carlin-Type Gold Deposits in China. Mineralium Deposita, 37, 378-392. https://doi.org/10.1007/s00126-001-0242-7

[55] Laznicka, P. (2006) Giant Metallic Deposits-Future Sources of Industrial Metals. Springer, Berlin, $732 \mathrm{p}$.

[56] Hallbauer, D.K. and Barton, J.M. (1987) The Fossil Gold Placers of the Witwatersrand. Gold Bulletin, 20, 68-79. https://doi.org/10.1007/BF03214660

[57] Phillips, N.G. and Law, J.D.M. (1994) Metamorphism of the Witwatersrand Gold Fields: A Review. Ore Geology Reviews, 9, 1-31. https://doi.org/10.1016/0169-1368(94)90017-5

[58] Barnicoat, A.C., Henderson, I.H.C., Knipe, R.J., Yardley, B.W.D., Napier, R.W., Fox, N.P.C., Kenyon, A.K., Muntingh, D.J., Strydom, D., Winkler, K.S., et al. (1997) Hydrothermal Gold Mineralization in the Witwatersrand Basin. Nature, 386, 820-824. https://doi.org/10.1038/386820a0

[59] Mathur, R., Gauert, C., Ruiz, J. and Linton, P. (2013) Evidence for Mixing of Re-Os Isotopes at $<2.7 \mathrm{Ga}$ and Support of a Remobilized Placer Model in Witwatersrand Sulfides and Native Au. Lithos, 164-167, 65-73.

https://doi.org/10.1016/j.lithos.2012.11.015

[60] Sestini, G. (1973) Sedimentology of a Plaeoplacer: Tho Gold-Bearing Tarkwain of Ghana. In: Amstutz, G.C. and Bernard, A.J., Eds., Ores in Sediments, Springer-Verlag, Heidelberg, 275-305. https://doi.org/10.1007/978-3-642-65329-2_21

[61] Davis, D.W., Hirdes, W., Schaltegger, U. and Nunoo, E.A. (1994) U-Pb Age Constraints on Deposition and Provenance of Birimian and Gold-Bearing Tarkwaian Sediments in Ghana, West Africa. Precambrian Research, 67, 89-107. https://doi.org/10.1016/0301-9268(94)90006-X

[62] Oberthür, T., Vetter, U., Davis, D.W. and Amanor, J.A. (1998) Age Constraints on Gold Mineralization and Paleoproterozoic Crustal Evolution in the Ashanti Belt of Southern Ghana. Precambrian Research, 89, 129-143.

https://doi.org/10.1016/S0301-9268(97)00075-2

[63] Milési, J.P., Ledru, P., Marcoux, E., Mougeot, R., Johan, V., Lerouge, C., Sabaté, P., Bailly, L., Respaut, J.P. and Skipwith, P. (2002) The Jacobina Paleoproterozoic Gold-Bearing Conglomerates, Bahia, Brazil $\mu$ a "Hydrothermal Shear-Reservoir" Model. Ore Geology Reviews, 19, 95-136. https://doi.org/10.1016/S0169-1368(01)00038-5

[64] Meier, D.L., Heinrich, C.A. and Watts, M.A. (2009) Mafic Dikes Displacing Witwatersrand Gold Reefs: Evidence against Metamorphic-Hydrothermal Ore Formation. Geology, 37, 607-610. https://doi.org/10.1130/G25657A.1

[65] Phillips, N.G. and Law, J.D.M. (1994) Metamorphism of the Witwatersrand Gold Fields: A Review. Ore Geology Reviews, 9, 1-31. https://doi.org/10.1016/0169-1368(94)90017-5

[66] Ruiz, J., Valencia, V.A., Chesley, J.T., Kirk, J., Gehrels, G. and Frimmel, H. (2006) Thesource of Gold for the Witwatersrand from Re-Os and U-Pb Detrital Zircon Geochronology. Geochimica and Cosmochimica Acta, 70, A543. https://doi.org/10.1016/j.gca.2006.06.1002

[67] Schaefer, B.F., Pearson, D.G., Rogers, N.W. and Barnicoat, A.C. (2010) Re-Os Isotope and PGE Constraints on the Timing and Origin of Gold Mineralisation in the Witwatersrand Basin. Chemical Geology, 276, 88-94. 
https://doi.org/10.1016/j.chemgeo.2010.06.001

[68] Goldfarb, R.J., Phillips, G.N. and Nokleberg, W.J. (1998) Tectonic Setting of Synorogenic Gold Deposits of the Pacific Rim. Ore Geology Reviews, 13, 185-218.

https://doi.org/10.1016/S0169-1368(97)00018-8

[69] Goryachev, N.A. and Pirajno, F. (2014) Gold Deposits and Gold Metallogeny of Far East Russia. Ore Geology Reviews, 59, 123-151.

https://doi.org/10.1016/j.oregeorev.2013.11.010

[70] Goldfarb, R., Baker, T., Dubé, B., Groves, D.I., Hart, C.J.R. and Gosselin, P. (2005) Distribution, Character, and Genesis of Gold Deposits in Metamorphic Terranes. Economic Geology 100 th Anniversary Volume, 407-450.

[71] Dubé, B. and Gosselin, P. (2007) Greenstone-Hosted Quartz-Carbonate Vein Deposits. In: Mineral Deposits of Canada: A Synthesis of Major Deposit-Types, District Metallogeny, the Evolution of Geological Provinces, and Exploration Methods, Geological Association of Canada, Mineral Deposits Division, 49-73.

[72] Condie, K.C. (2000) Episodic Continental Growth Models: Afterthoughts and Extensions. Tectonophysics, 322, 153-162.

https://doi.org/10.1016/S0040-1951(00)00061-5

[73] Hawkesworth, C.J., Dhuime, B., Pietranik, A.B., Cawood, P.A., Kemp, A.I.S. and Storey, C.D. (2010) The Generation and Evolution of the Continental Crust. Journal of the Geological Society, 167, 229-248. https://doi.org/10.1144/0016-76492009-072 